\title{
10 Bright Basins - Do Many Bright Spots Make a Basin Shine?
}

\author{
Francis Gichuki* and David Molden** \\ International Water Management Institute, PO Box 2075, Colombo, Sri Lanka; \\ e-mails:*f.gichuki@cgiar.org; ${ }^{* *}$ d.molden@cgiar.org
}

\section{Introduction}

Attaining the Millennium Development Goals in developing countries, where land and water resources are scarce, calls for sustainable increases in productivity-led agricultural growth. This has been achieved in areas where individuals and communities have adopted resource-conserving and yield-enhancing technologies and management practices to increase the goods and services provided by a given land unit. Such areas are commonly referred to as 'bright spots'. Bright spots offer the following local benefits to the individuals and communities that create them: (i) increased agricultural output and income; (ii) improved soil fertility; (iii) enhanced productivity of scarce land, water, nutrients, labour, energy and capital resources; and (iv) improved agrobiodiversity and enhanced resilience (Bossio et al., 2004; Noble et al., 2006). Bright spots also offer additional society-wide benefits such as: (i) increasing employment opportunities and income; (ii) empowerment of local communities for more effective technology transfer; (iii) better utilization of local skills and resources; (iv) creating opportunities for the poor to enhance land- and wateruse benefits; ( $v$ ) enhanced carbon sequestration; and (vi) reduced vulnerability.

Bright spots are most often defined at farm or community levels, and it is assumed that their scaling-up will result in a better situation for all. Examining bright spots using a basin perspective raises questions associated with their scaling-up. First, a bright spot in one location may cause problems elsewhere in a basin. How can the extent of the problems and associated losses be reduced? Second, bright spots can also benefit hydrologically linked communities by improving the water situation in terms of quantity, quality and timing. What water cost and benefit-sharing arrangements should upstream and downstream communities establish to manage externalities in ways that are acceptable to all? Third, bright spots benefits do not generally scale-up linearly; that is, if a bright spot creates one unit of net benefit, one hundred bright spots will not necessarily generate a hundred units of net benefit. The unit benefit tends to decline while the cost of establishing subsequent bright spots tends to increase, mainly because later bright spots emerge in less favourable areas. The very poor, in less favourable areas, tend to be late adopters and generally fail to seize opportunities arising from such bright spots. What propoor strategies are needed to facilitate the adoption of bright spot technologies by the poor in less favorable areas? And fourthly, would widespread adoption of bright spot technologies enhance basin-wide total net benefits, equitably and sustainably?

This chapter sets out to answer some of these questions. We do this by developing an analytical 
framework to improve our understanding of the complex interplay between bright spots and water-related externalities and of options for optimizing basin-wide benefits associated with bright spots. We use the analytical framework to better understand how bright spots and their externalities have been managed in three case study areas. Then we draw lessons from these case studies on how bright spots can effectively contribute to addressing basin-wide land degradation challenges and to enhancing total net benefits equitably and sustainably (and so make a basin shine more brightly).

\section{Analytical Framework}

This analytical framework seeks to enhance understanding of: (i) flows in and out of a land unit, the relative contribution of water-related flows and how these flows influence the productivity status of a land unit; (ii) water-related externalities and how they are transmitted from one land unit to another; and (iii) impacts of externalities and strategies for managing them.

\section{Flows as determinants of the productivity status of a land unit}

The productivity status of a given land unit is determined by stocks and internal processes and whether or not they create more favourable soil characteristics for plant and animal production. Insofar as plants are concerned, the main constituent stocks that determine their productivity include soil depth, soil organic matter, plant nutrients, soil water, soil oxygen content, salts in the soil, and weeds, pests and disease. These stocks are mainly determined by natural- and human-induced flows and to a limited extent by internal process such as nitrogen fixation. The main flows are: (i) lateral inflows and outflows of water, soil, organic matter, nutrients, salts, pests, disease and seeds; (ii) externally sourced input flows such as agrochemicals; (iii) internal recycling flows such as the use of crop residues and farmyard manure; and (iv) export flows associated with harvested material removed from that land unit. The consequences of these flows on the constituent stock and the productivity status of the land unit are summarized in Table 10.1.
Analysis of different flow components and their impact on the productivity status of land units is particularly useful in assessing the relative importance of lateral flows and their on- and offsite impacts.

\section{Externalities and their hydrological linkages}

An externality occurs when an action by one agent results in an intended or unintended cost or benefit to a third party. Externalities occur where the following coexist: (i) there are lateral flows across a landscape; (ii) there are people that deliberately or accidentally reduce or increase lateral flows and associated costs or benefits to a third party; and (iii) there are people who bear the costs or receive the benefits associated with changes in the nature and magnitude of a lateral flow from one land unit to another (Swallow et al., 2001; van Noordwijk et al., 2004). Within a basin, the main lateral flows that produce externalities are water, soil particles and nutrients, plants, animals and microorganisms, chemical compounds, fire, smoke and greenhouse gases. We confine ourselves to externalities associated with water flows and the associated translocation of soil particles, microorganisms, nutrients and other chemical compounds. Examples of potential externalities associated with bright spots are presented in Table 10.2. Understanding the types of externalities and hydrological links between them helps us identify land units that cause the externalities, ameliorate or aggravate them, and the people who are affected by the externality. The managers of these land units are the key stakeholders to be involved in assessing the nature, extent and value of the externalities and in negotiating response options.

The externalities identified in Table 10.2 are transmitted by lateral water flows: (i) along hill slopes; (ii) from hill slope to a valley bottom; (iii) from a land unit to a water body; (iv) from one river reach to another; ( $v$ ) from river mouth to receiving water body (inland lake or sea); and (vi) also flows associated with soil water and groundwater interaction, and surface water and groundwater interactions. The nature, extent and impact of the externality are shaped and determined by: (i) the magnitude of the externality at its most upstream source location; (ii) cumulative effects (additions and removals) as it 
Table 10.1. Flow components influencing productivity status.

\begin{tabular}{|c|c|c|}
\hline \multirow[b]{2}{*}{ Flow component } & \multicolumn{2}{|c|}{ Examples of productivity consequences of flows in a given land unit } \\
\hline & Productivity-enhancing & Productivity-degrading \\
\hline $\begin{array}{l}\text { Lateral inflows of water and } \\
\text { associated material }\end{array}$ & $\begin{array}{l}\text { Incoming water } \\
\text { - improves soil moisture regime and reduces drought stress } \\
\text { - maintains groundwater at acceptable levels } \\
\text { - reduces concentration of harmful elements } \\
\text { Incoming material } \\
\text { - increases nutrient and organic matter content of the soil }\end{array}$ & $\begin{array}{l}\text { Incoming water } \\
\text { - increases water-logging stress } \\
\text { Incoming material } \\
\text { - pollutes water resources } \\
\text { - degrades the soil (increased salts and nutrient imbalance) } \\
\text { - degrades aquatic ecosystem (temperature changes, turbidity, } \\
\text { eutrophication) } \\
\text { - increases weed, pest and disease incidences }\end{array}$ \\
\hline $\begin{array}{l}\text { Internal recycling of water, crop } \\
\text { residue and animal waste }\end{array}$ & $\begin{array}{l}\text { Enhances soil fertility through the use of crop residue and } \\
\text { manure } \\
\text { Improves soil moisture conservation through appropriate } \\
\text { use of crop residue and manure } \\
\text { Augments water supply through storage and redistribution } \\
\text { within the land unit }\end{array}$ & $\begin{array}{l}\text { Build-up of weeds, pests and diseases associated with the use of crop } \\
\text { residue, animal waste and farmyard manure }\end{array}$ \\
\hline $\begin{array}{l}\text { External inputs (agricultural } \\
\text { chemicals) }\end{array}$ & $\begin{array}{l}\text { Enhances plant nutrient stocks } \\
\text { Restores nutrient balance and } \mathrm{pH} \text { to required level } \\
\text { Reduces stock of weeds, pests and diseases }\end{array}$ & $\begin{array}{l}\text { Creates an imbalance in nutrient stock } \\
\text { Takes } \mathrm{pH} \text { out of the acceptable range } \\
\text { Promotes growth of undesirable microorganisms, flora and fauna }\end{array}$ \\
\hline $\begin{array}{l}\text { Lateral outflows through natural } \\
\text { and artificial drainage }\end{array}$ & Removes excess water and salts & $\begin{array}{l}\text { Runoff that increases drought stress } \\
\text { Soil erosion and nutrient loss associated with runoff and deep percolation } \\
\text { Groundwater decline below acceptable levels }\end{array}$ \\
\hline $\begin{array}{l}\text { Export outflows associated with } \\
\text { removal of plant biomass }\end{array}$ & $\begin{array}{l}\text { Reduces weeds, pest and disease stock through export } \\
\text { of crop residue }\end{array}$ & $\begin{array}{l}\text { Lowers plant nutrient stock } \\
\text { Reduces soil organic matter }\end{array}$ \\
\hline
\end{tabular}


Table 10.2. Potential externalities associated with bright spots.

\begin{tabular}{|c|c|c|}
\hline \multirow[b]{2}{*}{ Bright spot elements } & \multicolumn{2}{|c|}{ Potential externality } \\
\hline & Positive & Negative \\
\hline $\begin{array}{l}\text { Bright spots that reduce runoff } \\
\quad \text { and soil loss } \\
\text { Water harvesting and storage } \\
\text { Soil conservation measures } \\
\text { Conservation tillage } \\
\text { Mulching }\end{array}$ & $\begin{array}{l}\text { Reduced sedimentation } \\
\text { in downstream water bodies } \\
\text { Reduced water pollution } \\
\text { Reduced risk of flooding } \\
\text { Groundwater recharge and } \\
\text { sustained base flow }\end{array}$ & $\begin{array}{l}\text { Lower output and profits of production } \\
\text { system dependent on upstream } \\
\text { sediments and their nutrient content } \\
\text { Reduced catchment water yield }\end{array}$ \\
\hline $\begin{array}{l}\text { Bright spots that rely on external } \\
\text { agricultural chemical inputs } \\
\text { Use of fertilizer } \\
\text { Use of pesticides and herbicides }\end{array}$ & $\begin{array}{l}\text { Increased water availability } \\
\text { attributed to water saving } \\
\text { associated with higher water } \\
\text { productivity }\end{array}$ & $\begin{array}{l}\text { Water pollution } \\
\text { Degradation of aquatic ecosystem }\end{array}$ \\
\hline $\begin{array}{l}\text { Small reservoirs as a community } \\
\quad \text { bright spot } \\
\text { Dam } \\
\text { Catchment conservation } \\
\text { Supplemental irrigation } \\
\text { Aquaculture }\end{array}$ & $\begin{array}{l}\text { Reduced sediment loading on } \\
\text { downstream aquatic } \\
\text { ecosystems } \\
\text { Reduced river water depletion } \\
\text { during the dry season } \\
\text { Reduced risk of flooding }\end{array}$ & $\begin{array}{l}\text { Reduced catchment water yield } \\
\text { Reduced dry-season flows } \\
\text { Reduced benefits associated with } \\
\text { flooding }\end{array}$ \\
\hline $\begin{array}{l}\text { Run-of-the-river irrigation bright spots } \\
\text { Traditional irrigation systems } \\
\text { Bucket-fed drip irrigation } \\
\text { Small basins }\end{array}$ & $\begin{array}{l}\text { Reduced human pressure on } \\
\text { forest, wetland and grassland } \\
\text { ecosystem }\end{array}$ & $\begin{array}{l}\text { Reduced dry-season flow } \\
\text { Salinization of groundwater }\end{array}$ \\
\hline $\begin{array}{l}\text { Groundwater irrigation bright spots } \\
\text { Shallow wells } \\
\text { Water-lifting technologies (human-, } \\
\text { solar-, wind- and fossil } \\
\text { fuel-powered pumps) }\end{array}$ & $\begin{array}{l}\text { Reduced human pressure on } \\
\text { surface water resources }\end{array}$ & $\begin{array}{l}\text { Reduced dry-season river flow } \\
\text { Seawater intrusion associated with the } \\
\text { depletion of fresh groundwater } \\
\text { resources } \\
\text { Groundwater pollution }\end{array}$ \\
\hline
\end{tabular}

cascades along the water pathway; (iii) the quantities, flow rate and timing of water flow, which transmit the externality from one location to another; (iv) water pathways that determine the hydrological connectivity of different land units and their users; (v) drainage network and topography, which create source and sink areas; and (vi) the way in which different externalities combine in a given location and whether they aggravate or abate the impacts (Table 10.3).

The externalities and options for managing them are dependent on location and seasonal (or temporal) and spatial scales. While the impact of externalities at very local scales may be evident, such a perspective will fail to capture the evolution of such externalities across space and particularly the cumulative effect of externalities from other parts of the basin. Similarly, a focus on flows during only one or several seasons may fail to capture the externalities associated with the cumulative effect of slow processes such as groundwater pollution, reservoir siltation and a gradual decline in dry-season river flows. A basin-scale focus may well reveal hotspot sources without capturing cumulative effects at local scales, which may collectively make the largest contribution to a problem. Hence, the need to scope for externalities at nested spatial and temporal scales.

\section{The impacts of externalities and strategies for managing them}

The third condition for an externality to occur is that there are people who bear the costs or receive the benefits associated with changes in the nature and magnitude of lateral flow from one land unit to another (van Noordwijk et al., 2004). In the past, upstream development projects were planned and implemented without adequately considering negative externalities, 
Table 10.3. Externality pathways and management options.

\begin{tabular}{|c|c|c|}
\hline Externality pathway & Description & Options for managing externality \\
\hline Flow along a hill slope & $\begin{array}{l}\text { Lateral water flows along a hill slope transmit externalities } \\
\text { from one farm to another, through overland, interflow or } \\
\text { channel flow }\end{array}$ & $\begin{array}{l}\text { Shield farm/fields by safely evacuating the excess water to a natural } \\
\text { waterway } \\
\text { Utilize inflows to enhance productivity }\end{array}$ \\
\hline Flow from hill slope to a valley bottom & $\begin{array}{l}\text { A transition from steep-sloping to gentle-sloping land slows lateral } \\
\text { flows and creates opportunities for abating the externality; for } \\
\text { example, marshes and swamps acting as filters }\end{array}$ & $\begin{array}{l}\text { Construct buffer strips to reduce externalities to acceptable levels } \\
\text { Change land use in valley bottom to one that is impacted positively } \\
\text { by the externalities }\end{array}$ \\
\hline Flow from a land unit to a water body & Overland flow into the river channel & $\begin{array}{l}\text { Maintain riparian buffer strips to reduce externalities to } \\
\text { acceptable levels }\end{array}$ \\
\hline $\begin{array}{l}\text { Subsurface flow associated with soil } \\
\text { water-groundwater interaction }\end{array}$ & $\begin{array}{l}\text { Soil water and groundwater interface transfers externalities from: } \\
\text { the soil to the groundwater, such as nitrate pollution of } \\
\text { groundwater, or enhances groundwater recharge; and } \\
\text { the groundwater to the soil, such as groundwater-induced } \\
\text { soil salinization, or a favourable soil regime }\end{array}$ & $\begin{array}{l}\text { Reduce soil pollutant stock } \\
\text { Reduce groundwater recharge if groundwater rise has a negative } \\
\text { impact on soil productivity } \\
\text { Tap groundwater to a level that does not negatively impact soil } \\
\text { productivity }\end{array}$ \\
\hline $\begin{array}{l}\text { Subsurface flow associated with } \\
\text { surface water-groundwater } \\
\text { interaction }\end{array}$ & $\begin{array}{l}\text { Groundwater augments surface flow and surface water } \\
\text { recharges groundwater along the river profile. This interaction } \\
\text { can transfer externalities from surface to groundwater and } \\
\text { vice versa }\end{array}$ & $\begin{array}{l}\text { Manage the interaction in ways that reduce the transmission of } \\
\text { externalities }\end{array}$ \\
\hline Flow from one river reach to another & $\begin{array}{l}\text { Transfer of water from one reach to the next transfers } \\
\text { externalities downstream }\end{array}$ & $\begin{array}{l}\text { Use natural and man-made wetlands to shield downstream reaches } \\
\text { from negative externalities }\end{array}$ \\
\hline $\begin{array}{l}\text { Flow from river mouth to receiving } \\
\text { water body }\end{array}$ & $\begin{array}{l}\text { The complex interaction of surface, groundwater and seawater } \\
\text { that exists at river outlets determines the nature and extent of } \\
\text { seawater intrusions, sedimentation and expansion of river } \\
\text { deltas, rise or fall of coastal groundwater levels }\end{array}$ & $\begin{array}{l}\text { Reduce negative externalities of river modification } \\
\text { Manage sea-fresh water interaction in coastal areas }\end{array}$ \\
\hline
\end{tabular}


particularly those affecting the environment and the poor. In other cases, the concerns of downstream communities are simply ignored, perhaps because they are in any case marginalized or are in a downstream riparian country. Barbier (2003) argues that failing to take into consideration the negative externalities of upstream development is poor economics, as it increases the benefits to an upstream community at the expense of a downstream community. To avoid such costly mistakes, there is a growing recognition of the need to use ex ante impact assessment as a basis for decision making on whether to proceed with an upstream project, and if so, how to plan and implement it in ways that minimize negative externalities.

To address the key question raised in the title of this chapter, the impacts of bright spots and their externalities need to be understood and strategies put in place to minimize negative impacts. We surmise that a basin shines more brightly as total net benefits increase, as the distribution of benefits among basin inhabitants becomes more equitable and as the provision of the desired goods and services become more sustainable. Indicators of local impact, change in total basin-wide net benefits, equity and sustainability are needed to communicate information on the extent to which a basin shines and to identify areas requiring improvement (see Table 10.4). In practice, these measures will be difficult to quantify for both ex ante and ex post impact assessment, but could be included in a checklist of variables that should be taken into consideration and the outcomes discussed and negotiated as a part of planning and adaptive management processes.

Externalities can be managed at source, at some intermediate land unit (such as a wetland) and at the land unit where their impact is experienced. Externalities can be managed in a variety of ways, but are usually addressed through reactive approaches, which tend to address problems on an ad hoc basis.

\section{Case Studies on Bright Spots and Externalities}

\section{Case study contexts}

Three case studies are used here to explore issues associated with bright spots, their evolution, their externalities and how these are managed. We focus on bright spots arising from the adoption of resource-conserving agriculture (Machakos and Yellow River basin) and of technological and management practices for water quality improvements (New York City watersheds).

\section{Soil and water conservation interventions in Machakos watersheds}

The upper watersheds of the Athi River basin, situated in Kenya's Machakos district, cover an area of $13,700 \mathrm{~km}^{2}$ and experienced severe vegetation and soil degradation in the 1930s. The combined effect of degradation and recurrent droughts depressed crop and livestock outputs and created the perception, amongst colonial administrators, that the district's farming systems were unsustainable and in some cases in a state of terminal decline. In 1937, Maher was to comment

\section{[e]very phase of misuse of land is vividly and poignantly displayed in this Reserve, the inhabitants of which are rapidly drifting to a state of hopeless and miserable poverty and their land to a parching desert of rocks, stones and sand.}

(Colin Maher, Senior Soil Conservation Officer, 1937 quoted in Tiffen et al., 1994)

Low agricultural outputs and an increasing population led to further conversion of forest, grassland and wetlands into cropland and in most cases continued vegetation, soil and water degradation (Tiffen et al., 1994). By the 1960s many springs were reported to have dried up, and approximately $63 \%$ of the surface reservoirs were completely silted up (Gichuki, 1991).

A series of programmatic interventions promoted soil and water conservation and good farming practices (Gichuki, 1991; Thomas, 1991). Soil and water conservation measures, particularly terracing, were adopted by $78 \%$ of farmers, with on-farm coverage varying from 15 to $95 \%$. Soil and water conservation and good farming practices contributed to alleviating water and fertility constraints to crop production and supported agricultural intensification, diversification and in some cases a shift to high-value crops. A typical farm had cut-off drains, on-field soil conservation structures and bananas planted in pits. Runoff harvesting for crop production, 
Table 10.4. Impact indicators.

\begin{tabular}{|c|c|}
\hline Indicator & Measures \\
\hline $\begin{array}{l}\text { Local impact: what are the } \\
\text { total benefits derived from } \\
\text { bright spots? }\end{array}$ & $\begin{array}{l}\text { Productivity - ratio of output to input, which serves as a measure of the } \\
\text { relative suitability of a bright spot or a measure of resource-use } \\
\text { efficiency } \\
\text { Incremental yield or income over the traditional system } \\
\text { Profitability - net benefit accruing from the bright spot } \\
\text { Stability/reliability/resilience - the absence or minimization of season- } \\
\text { to-season or year-to-year fluctuations in the level and/or value of } \\
\text { output of a bright spot } \\
\text { Diversity - risk-minimizing strategy associated with: (i) diversification of } \\
\text { the production system - crop, livestock, trees, fisheries within the } \\
\text { bright spot; (ii) diversity of outputs from a given bright spot, for } \\
\text { example milk, meat and draught power from cattle production; } \\
\text { (iii) diversity of the ways that the produce is used - consumed, sold, } \\
\text { stored, processed; and (iv) diversity of income sources } \\
\text { Time dispersion - the degree to which production inputs, output and } \\
\text { income are spread over time }\end{array}$ \\
\hline $\begin{array}{l}\text { Change in total basin-wide } \\
\text { net benefit: is the basin } \\
\text { community better off } \\
\text { economically than it was } \\
\text { before? }\end{array}$ & $\begin{array}{l}\text { Number of land units negatively impacted } \\
\text { Number of land units positively impacted } \\
\text { Total economic loss arising from negative impacts } \\
\text { Total net benefits arising from positive impacts } \\
\text { Change in total basin-wide net benefit (amount and \%) } \\
\text { Change in total net benefit in most vulnerable periods } \\
\text { Change in total net benefit in most vulnerable areas } \\
\text { Change in total net benefit to the most vulnerable communities }\end{array}$ \\
\hline $\begin{array}{l}\text { Equity: do the interventions } \\
\text { enhance equity among the } \\
\text { current generation and } \\
\text { contribute to inter-generation } \\
\text { equity? }\end{array}$ & $\begin{array}{l}\text { Change in total net benefit in most vulnerable periods } \\
\text { Change in total net benefit in most vulnerable areas } \\
\text { Change in total net benefit to the most vulnerable communities } \\
\text { Gini coefficient }\end{array}$ \\
\hline $\begin{array}{l}\text { Sustainability: to what extent } \\
\text { are bright spots contributing } \\
\text { to providing a healthy, } \\
\text { productive, meaningful life } \\
\text { for all (present and future)? }\end{array}$ & $\begin{array}{l}\text { Trends of benefit, equity and natural resource status in relationship to } \\
\text { the baseline condition }\end{array}$ \\
\hline
\end{tabular}

mulching, manuring, mixed cropping with fruit trees, beans and maize, and live fences used as windbreaks and as a source of fuelwood were common practices. With improved management of grazing land, livestock-carrying capacity rose from only 0.24 to 0.33 livestock units supported per ha to 0.63-2.50 livestock units per ha, depending on agroclimatic conditions and the nature and extent of pasture improvement.

Local bright spots emerged in site-specific locations to take advantage of a variety of enabling conditions and potential benefits, including proximity to the road and market, runoff accumulation, soil and water conservation incentives, high-yielding crop varieties, and so on. These changes came about against a background of strong social capital, which accelerated the adoption of high-yielding and resource-conserving technologies (Tiffen and Gichuki, 2000). A wide range of bright spots scattered throughout the upper watersheds increased agricultural output from 0.4 to $1.2 \mathrm{t} /$ capita between 1932 and 1989. During the same period, the farm value output per ha increased fivefold and the agricultural economy (mainly coffee, fruit, vegetable and food crops and livestock) supported a sixfold increase in human population (Tiffen et al., 1994). The siltation of reservoirs declined and dry-season river flows improved (Gichuki, 1991). 


\section{Soil and water conservation in Yellow River basin}

The Yellow River is considered to be the most sediment-laden river in the world, with a longterm average sediment delivery of 1.2 billion $\mathrm{mt} /$ year (Fu and Chen, 2006; Wang et al., 2007). The Loess Plateau contributes $80-90 \%$ of the river's total sediment load, and approximately $191,000 \mathrm{~km}^{2}$ of land on the plateau loses $5000 \mathrm{t} / \mathrm{km}$ annually (YRCC, 2001). Each year approximately 400 million t of sediment is trapped in the reservoirs and irrigation systems of the basin. Of the sediment entering irrigation systems, approximately $40 \%$ ends up on irrigated fields, where it has positive impacts on crop yields (Giordano et al., 2004). Another 400 million $t$ silts the river channel and the rest is deposited at the river's mouth. As a consequence, the Yellow River delta grows by 0.42 $\mathrm{km}^{2}$ and adds $23.5 \mathrm{~km}^{2}$ of land every year to the coast (Yan-chun, 1998).

In the Yellow River basin, the main factors that constrain the emergence of bright spots over the entire Loess Plateau are: (i) unfavourable biophysical conditions - steep slopes, highly erodible soils and erosive rainstorms; (ii) the high costs of rehabilitating degraded land; (iii) conflicting policy objectives; and (iv) concerns that although re-vegetation and the construction of key dams reduces the sediment load, these measures also reduce water yield and availability for downstream uses (Lu and van Ittersum, 2003; Xing-min et al., 2004). A series of programmatic, community-level and individual interventions have alleviated some of the above problems. We highlight those associated with the Loess Plateau Watershed Rehabilitation Project (LPWRP), which was launched in 1994 and completed in 2002. This programme made a direct investment of US\$250 million, which spurred the emergence of many bright spots in the $15,600 \mathrm{~km}^{2}$ area in which it operated. The main project achievements included the terracing of 90,500 ha, the afforestation of 90,900 ha, and shrub trees were planted across 136,000 ha. In addition, 7100 ha of irrigation was developed, and 149 key dams were constructed along with other dam and control structures (Shaojun et al., 2004). This ingenious system of dams created fertile farming land, provided flood defences and water storage for dry-season use in what were once deep gullies (Chunhong et al., 2004). The above interventions, combined with other agricultural and marketing interventions, are reported to have contributed to increasing grain output from 427,000 to $700,000 \mathrm{mt}$, fruit production from 80,000 to $345,000 \mathrm{mt}$ and farmers' incomes from US $\$ 44$ to US $\$ 155$ (Shaojun et al., 2004).

There is some controversy over whether these bright spots save water for the basin, specifically whether or not it improves the flow regime in the lower reaches. The two contrasting views are: (i) while upstream conservation works do save water, these savings are rapidly used up in situ to increase production, yielding no benefits to downstream water users; and (ii) water is saved because the programme has reduced the water requirements for sediment flushing downstream. Studies have established that the vegetative measures of soil erosion control deplete 3-16 $\mathrm{m}^{3}$ of water through evapotranspiration for a reduction of one $t$ of sediment in the lower reaches, whereas flushing one $\mathrm{t}$ of sediment requires 33-60 $\mathrm{m}^{3}$ (Xing-min et al., 2004). Based on this relationship, it was estimated that between 1970 and 1996, soil and water conservation practices reduced soil loss by an average of $1.495 \times 10^{8} \mathrm{mt}$ annually in the river section between Hekou and Longmen and saved $4.88 \times 10^{9} \mathrm{~m}^{3}$ of water that would have been needed to flush out sediments.

\section{Water quality improvements in New York watersheds}

New York City gets its water from Catskill/ Delaware and Croton watersheds. The decline of the rural economy - based mainly on family farm agriculture, woodlot forestry and outdoor recreational tourism - triggered land-use and management changes, mainly agricultural intensification, commercial forestry, road construction, vacation homes and urban centres (Appleton, 2002). Securing livelihoods for the watershed communities through commercial agriculture (locally perceived bright spots) created externalities associated with increasing point and non-point source pollution. Industrial livestock production units were the main source 
of water pollutants. Environmental regulations aimed at reducing pollution were ineffective at controlling these externalities.

\begin{abstract}
Traditional models of command and control regulation did not work when the economic livelihood of individual farmers and other rural landowners was at stake. Non-point source water quality regulations had and have failed to articulate a clear coherent set of obligations for individual landowners to follow, and have never given such landowners any incentive to follow them.
\end{abstract}

(Appleton, 2002, p. 3)

Watershed communities, struggling to remain in business, viewed water quality regulation as unrealistic, arbitrary and top-down thinking by urban interests.

According to Appleton (2002), proactive approaches to addressing the problem were urgently needed, since allowing the deterioration of water quality in the watersheds and then spending massive sums to treat it was not considered an ideal solution to the problem. To meet strict water quality guidelines, New York City had two options to deal with the pollution problem to upgrade water treatment works or provide incentives for the watershed communities to undertake interventions aimed at reducing water pollution. A series of studies established that watershed water quality improvement at a cost of US $\$ 1.5$ billion invested over a 10 -year period was cheaper than upgrading the New York City water treatment facilities at a capital and annual operating cost of US\$6 billion and US $\$ 300$ million, respectively (Perrot-Maitre and Davis, 2001). For many, addressing non-point pollution associated with both agriculture and suburban development through a watershed management programme was unlikely to succeed (Appleton, 2002). After much consultation and negotiation, however, stakeholders agreed on a package of innovative financing arrangements to facilitate water quality improvements in the watersheds. The intervention package included: (i) purchase of land from willing sellers at full market price to ensure that it was conserved in such a way that enhanced its natural water-filtering capabilities; (ii) conservation easements - a transfer of usage rights, which created a legally enforceable land preservation agreement; (iii) upgrading water treatment, sewage and storm water management facilities; and (iv) supporting the implementation of best management practices in forests, farms and riparian zones (Perrot-Maitre and Davis, 2001).

Although the programme to implement best on-farm management practices was voluntary, its goal was to obtain the participation of $85 \%$ of all farmers within 5 years. The incentives and benefits to farmers, as well as the conservation ethic of some of them, resulted in $93 \%$ of farmers participating in the programme, a reduction of agricultural pollution by $75 \%$ and economic stabilization of farming in the watersheds (Appleton, 2002).

\section{Lessons Learnt from the Case Studies}

Bright spots emerge where biophysical, socioeconomic and institutional conditions are favourable (Noble et al., 2006). The emergence may be spontaneous or driven by programmatic interventions. In all the above case studies, the bright spots are closely linked to major development programmes. In the Machakos case study, a series of development projects created conditions in which most of the bright spots emerged spontaneously as communities and individuals took advantage of a series of favourable conditions. In the Yellow River, bright spots are concentrated in areas where soil and water conservation initiatives have been most successful. Hotspots still remain in the most fragile and heavily degraded parts of the Loess Plateau. In the case of the New York study, the financial incentives and technical support provided the impetus needed to adopt appropriate technologies and management practices.

\section{Lateral flows, bright spots and their externalities}

Bright spots can be brightened or dimmed by lateral flows. For example, on-farm runoff harvesting in dry areas entails sacrificing some land for runoff collection. Efforts to control sediment in the Yellow River basin using silt dams created opportunities for bright spots to develop where such dams created fertile cropland and secured dry-season irrigation water. In 
such cases, lateral flows were major determinants of land productivity. In the case of New York City, lateral flows associated with industrial livestock production units were the major source of a negative externality.

The presence of an intermediate land unit that provides a buffering effect plays a key role in shielding downstream communities from negative externalities. At the hill slope level, a cut-off drain may provide the required buffering, as was the case in Machakos. At the watershed level, small dams trap sediments, reducing flooding in valley bottoms and increasing dry-season water availability. Such developments therefore act as a buffer for communities immediately downstream. At the basin level, a combination of natural and man-made wetlands provides buffering for a number of externalities. In the Yellow River basin, sediment is a major component of the lateral flow, and when deposited in reservoirs and irrigation canals it increases operation and maintenance costs, but contributes to soil fertility enhancement when deposited in irrigation fields. $\mathrm{Li}$ and Zhang (2003) reported that organic matter, total nitrogen, total phosphorus and total potassium were $0.42,0.025,0.157$ and $2.16 \%$, respectively of the total sediment deposited in irrigation fields. The combined effect of soil conservation in upper watersheds and water storage and irrigation development in middle reaches since the 1950s has contributed to reducing sediment flow into the sea. Wang et al. (2007) reported that the mean annual (1990-2005) sediment load reaching the sea was 300 billion mt/year, one-third of the 1983 estimates. Dam reservoirs enhanced water supply in dry seasons and facilitated agricultural intensification and diversification but affected downstream communities in various ways.

The links between the bright spot and the area where externalities are felt are in some cases short and clearly evident, as in the case of hill slope runoff and erosion processes and their impact on a neighbouring farmer. In semi-arid areas of Machakos, downstream farmers benefit from runoff that they can store for supplemental irrigation but suffer from the sediment, particularly if siltation takes place in farm ponds and drainage ditches and/or contributes to road damage (Gichuki, 1991; Barron et al., 2003). In such a case, the impacts can be easily quantified and attributed to an upstream land user. In the New York City case study, there was an obvious and direct link, albeit diffused, between water quality deterioration and upstream land and water management practices. As the number of land and water users increases, however, it is difficult to pinpoint the sources, particularly if there are no clearly evident water pollution hotspots. In the Yellow River basin, for example, the links between soil erosion in the catchment and degradation in the delta are blurred because there are so very many potential hotspots within the basin.

\section{To what extent did basins shine and why?}

In all the above case studies, interventions comprised a wide range of measures implemented over a long period. Bright spots emerged at different times and synergistically contributed to arresting the degradation problem and improving productivity. Table 10.5 shows that there are multiple externalities associated with bright spots and they affect downstream communities in many diverse ways.

Performance measures (yield, soil loss, sedimentation, income, water use, water availability) employed in the study areas can be used to generate a rough indication of the extent to which these basins shine. These indicators suggest that some parts of these basins shine as a result of this variety of interventions. The full potential of bright spots has not, however, been tapped. This is attributed to the site-specific nature of some bright spots and to factors that constrain their widespread adoption. The total net benefit, equity and sustainability measures proposed in the framework are ideal but not achievable for lack of data. We note that the performance measures that are widely used fail to adequately capture both equity and sustainability considerations. They also present piecemeal information: for example, reporting on yield increases alone instead of providing complementary indicators that capture the effect of natural resources management and crop production technology on yields and how this varies under different climatic conditions.

Because bright spots emerge in locations with favourable marketing, social and biophysical conditions, benefits are not necessary equally shared by all. The Machakos case study illu- 
Table 10.5. Highlights of local impact and externalities.

\begin{tabular}{|c|c|c|}
\hline \multirow[b]{2}{*}{ Local impacts } & \multicolumn{2}{|c|}{ Externality } \\
\hline & Positive & Negative \\
\hline $\begin{array}{l}\text { Soil and water conservation in } \\
\text { Machakos catchments } \\
\text { Increased agricultural output } \\
\text { (0.2 to } 1.2 \mathrm{mt} / \mathrm{ha}) \\
\text { Soil loss reduced from } 53.3 \text { to } \\
16 \mathrm{mt} / \mathrm{ha} / \text { year } \\
\text { Reduced soil fertility loss and } \\
\text { associated replenishment cost } \\
\text { Increase groundwater recharge } \\
\text { (\% of rainfall that ends up as deep } \\
\text { percolation increased from } 3 \text { to } \\
15 \%) \text { and yields of local springs } \\
\text { Increased dry-season river flows }\end{array}$ & $\begin{array}{l}\text { Reduced reservoir } \\
\text { sedimentation (sediment } \\
\text { load reduced from } 5 \text { to } \\
1.2 \mathrm{~kg} / \mathrm{m}^{3} \text { ) } \\
\text { Increased dry-season river flows }\end{array}$ & $\begin{array}{l}\text { Reduced catchment water } \\
\text { yield due to increased } \\
\text { evapotranspiration from } \\
34 \text { to } 47 \% \text { of rainfall }\end{array}$ \\
\hline $\begin{array}{l}\text { Soil and water conservation in the } \\
\text { Yellow River basin } \\
\text { Increased agricultural output and } \\
\text { income (income rose from US } \$ 44 \\
\text { to US } \$ 155) \\
\text { Reduced soil loss by an average of } \\
1.495 \times 10^{8} \mathrm{t} \text { annually in the } \\
\text { section between Hekou and } \\
\text { Longmen } \\
\text { Reduced soil fertility loss and } \\
\text { associated replenishment cost } \\
\text { Increased groundwater recharge and } \\
\text { yields of local springs }\end{array}$ & $\begin{array}{l}\text { Reduced sedimentation } \\
\text { Reduction in water used for } \\
\text { sediment flushing (30-57 } \mathrm{m}^{3} \\
\text { of water saved for each } \mathrm{t} \\
\text { of soil retained in the upper } \\
\text { catchment) }\end{array}$ & $\begin{array}{l}\text { Reduced productivity of } \\
\text { agricultural production } \\
\text { systems dependent on } \\
\text { floods, sediment and } \\
\text { nutrients arising from } \\
\text { upstream degradation. } \\
\text { Reduced catchment water } \\
\text { yield due to increased } \\
\text { evapotranspiration }\end{array}$ \\
\hline $\begin{array}{l}\text { Water quality improvements in } \\
\text { New York watershed areas } \\
\text { Reduced health risk associated with } \\
\text { water pollution and inadequate } \\
\text { sewage works }\end{array}$ & $\begin{array}{l}\text { Improved water quality at a } \\
\text { lower cost (over US } \$ 4.5 \text { billion } \\
\text { saving) }\end{array}$ & \\
\hline
\end{tabular}

strates the fact that some bright spots can be established with very low capital inputs. Hence, opportunities are also available to the poor. Positive externalities do benefit poor communities utilizing wetlands and those who rely on sediment for their soil fertility enhancement and on runoff for supplemental irrigation. Certain levels of resource use in upstream areas may, however, result in upstream-downstream inequity. This is illustrated by Barbier (2003), who argues that the gains in irrigation benefits upstream of the Hadejia-Jama're and Hadejia Nguru floodplain wetlands accounted for approximately $3-17 \%$ of the losses in floodplain benefits. Specific economic losses associated with reduced flows into the floodplains included: (i) increased cost of domestic water - a $25 \%$ increase in domestic water collection time and increased cost of groundwater estimated at US\$0.12 per household for a $1 \mathrm{~m}$ drop in groundwater level; (ii) an annual loss of US $\$ 82,832$ to vegetable farmers for a US\$1 million drop in groundwater level; and (iii) a system-wide loss ranging between US\$2.6 million and US\$24 million, depending on the quantity and timing of floodwater releases from upstream dams.

\section{Conclusions and Recommendations}

Bright spots have high local and significant society-wide benefits, as noted in the case studies here and reported elsewhere (Bossio et 
al., 2004; Mati, 2004; Noble et al., 2006). The case studies illustrate that the way externalities cascade down a river system is complex and results in a combination of negative and/or positive impacts. The nature and extent of an externality is influenced by: (i) biophysical and chemical factors, which determine the quantity of the externality at source and how it accumulates or is transformed along the waterway; and (ii) human factors, which determine the value and cost attached to externalities. At the landscape and small-watershed scale, linkages are easier to establish. Beyond this scale, linkages are difficult to establish owing to: (i) complex pathways; (ii) long time lags; and (iii) difficulties in establishing attribution, particularly when other factors contribute to the externality. Externalities exhibit a high temporal variability, generally associated with rainfall and stream flow variability, with high peaks occurring infrequently and over short periods of time. Some externalities have very long time lags. For example, the hydrological impacts of deforestation may take a long time to become clearly evident because deforestation generally takes place over many years, with some areas experiencing recovery and others degrading; climatic variability may mask the effect and/or deforestation may be accompanied by other waterand land-use changes that may either abate or exacerbate the externality (Calder, 2004).

We conclude by noting that bright spots can play a key role in enhancing positive externalities and reducing negative externalities associated with agricultural production. Programmes and projects that seek to scale-up and -out bright spots-related technologies and management practices should identify externalities and assess their ex ante impacts. Interventions aimed at scaling-up bright spots should be guided by the following principles:

- Scale-up appropriate bright spots in ways that optimize positive and minimize negative externalities.

- Generate more local benefits from bright spot interventions.

- Manage externalities at appropriate scales by focusing on hotspots, critical links, key actors and major stakeholders.
We surmise that making a basin shine is often a slow process that needs to be supported by:

- Appropriate technical solutions, such as barrier and buffer strips placed at the edge of fields, farm boundaries and riparian zones that can effectively reduce the transmission of externalities, and good planning to avoid costly mistakes.

- Conducive legal frameworks, such as property rights to encourage long-term investment and enforceable agreements on compensation for environmental goods and services.

- Effective incentives, such as payments for environmental services and fair prices for goods and services, using approaches that reduce negative externalities.

- A usable knowledge base containing information on trade-offs, which facilitates multistakeholder consultation and negotiation.

- Supportive partnerships of key actors at different scales that work synergistically to secure sustainable development.

We argue that a basin perspective is required to manage externalities because of the complexity of linkages and the convolution of externalities as they move from farm to hill slope to watershed to sub-basin and ultimately to basin scale. Such a basin perspective would involve planning and implementing interventions at several spatial scales so as to achieve optimal levels of participation.

Research should focus more on generating the information needed to improve understanding of externalities and their impacts and to address trade-offs associated with alternative intervention strategies. Tools are also needed for quantifying and valuing externalities.

\section{Acknowledgement}

This study was conducted as part of CPWF/IWMI synthesis research. The authors acknowledge the constructive criticism provided by the reviewers. 


\section{References}

Appleton, A.F. (2002) How New York City used an ecosystem services strategy carried out through an urban-rural partnership to preserve the pristine quality of its drinking water and save billions of dollars. Paper for Forest Trends - Tokyo November 2002. http://www.forest-trends.org/ documents/meetings/ tokyo_2002/NYC_H2O_Ecosystem_Services.pdf

Barbier, E.B. (2003) Upstream dams and downstream water allocation: the case of the Hadejia-Jama'are floodplain, northern Nigeria. Water Resources Research 39 (11), 1311-1319.

Barron, J., Rockstrom, J., Gichuki, F. and Hatibu, N. (2003) Dry spell analysis and maize yields for two semiarid locations in East Africa. Agricultural and Forest Meteorology 117 (1-2), 23-37.

Bossio, D., Noble, A., Pretty, J. and Penning de Vries, F. (2004) Reversing land and water degradation: trends and bright spot opportunities. Paper presented at the SIWI/CA Seminar, Stockholm, Sweden, 21 August 2004.

Calder, I.R. (2004) Forest and water - closing the gap between public and science perceptions. Water Science and Technology 49 (7), 39-53.

Chunhong, H., Deyi, W., Jayakumar, R. and Ajisawa, S. (eds) (2004) Warping dams - construction and its effects on environment, economy, and society in Loess Plateau region of China. UNESCO Office Beijing report CN/2004/SC-HYD/PI/1, Beijing.

Fu, G. and Chen, S. (2006) Water crisis in the Yellow River: facts, reasons, impacts, and countermeasures. Water Practice \& Technology 1 (2), 45-53.

Gichuki, F.N. (1991) Environmental change and dryland management in Machakos district, Kenya 1930-1990. Conservation Profile, ODI Working Paper No. 56. Overseas Development Institute, London.

Giordano, M., Zhu, Z., Cai, X., Hong, S., Zhang, X. and Xue, Y. (2004) Water management in the Yellow River Basin: background, current critical issues and future research needs. Comprehensive Assessment Research Report 3. Comprehensive Assessment Secretariat, Colombo, Sri Lanka.

Li, Y. and Zhang, Z. (2003) Strategies for efficient water use with high sediment contents in the Yellow River basin. Paper presented at the International workshop on improved irrigation technologies and methods: research, development and testing. 54th Executive Council of ICID 20th European Regional Conference Montpellier, France, 14-19 September 2003. http://afeid.montpellier.cemagref.fr/Mpl2003/htm/Session_ Workshop_1.htm

Lu, C.H. and van Ittersum, M.K. (2003) A trade-off analysis of policy objectives for Ansai, the Loess Plateau of China. Agriculture, Ecosystems and Environment 102, 235-246.

Mati, B. (2004) Bright spots on technology-driven change in smallholder irrigation: case studies from Kenya. Paper presented at the NEPAD/IGAD regional conference on Agricultural Successes in the Greater Horn of Africa. International Water Management Institute, Nairobi, Kenya.

Noble, A.D., Bossio, D.A., Penning de Vries, F.W.T., Pretty, J. and Thiyagarajan, T.M. (2006) Intensifying agricultural sustainability: an analysis of impacts and drivers in the development of 'bright spots'. Comprehensive Assessment of Water Management in Agriculture, Research Report 13, Colombo, Sri Lanka.

Perrot-Maître, D. and Davis, P. (2001) Case studies of markets and innovative financial mechanisms for water services from forests. Forest Trends, Washington, DC.

Shaojun, C., Yue, W. and Yijie, W. (2004) The Loess Plateau Watershed Rehabilitation Project. Paper presented at the Scaling Up Poverty Reduction: a Global Learning Process and Conference, Shanghai, China, 25-27 May 2004.

Swallow, B.M., Garrity, D.P. and van Noordwijk, M. (2001) The effect of scales, flows and filters on property rights and collective action in watershed management. Water Policy 3 (6), 521-526.

Thomas, D.B. (1991) Soil erosion. In: Mortimore, M. (ed.) Environmental Change and Dryland Management in Machakos District, Kenya 1930-1990: Environmental Profile. ODI Working Paper No. 53. Overseas Development Institute, London, pp. 24-43.

Tiffen, M. and Gichuki, F. (2000) People, property and profits in watershed management: Examples from Kenya and elsewhere. In: Lal, R. (ed.) Integrated Watershed Management in the Global Ecosystem. CRC Press, Boca Raton, Florida, pp. 345-363.

Tiffen M., Mortimore, M. and Gichuki, F. (1994) More People, Less Erosion: Environmental Recovery in Kenya. John Wiley \& Sons, London.

Van Noordwijk, M., Poulsen, J. and Ericksen, P. (2004) Filters, flows and fallacies: methods for quantifying external effects of land use change. Agriculture, Ecosystems and Environment 104, 19-34. 
Wang, H.J., Yang, Z.S., Saito, Y., Liu, J.P., Sun, X.X. and Wang, Y. (2007) Stepwise decrease of the Huanghe (Yellow River) sediment load (1950-2005): impacts of climate change and human activities. Global and Planetary Change 57 (3-4), 331-354.

Xing-min, M., Fei, W., Rui, L. and Xiao-ping Z. (2004) Further discussion on the effect of soil and water conservation on water resources in the Yellow River Basin. Paper presented at the TASAE seminar, 9-15 November 2004. http://www.nourin.tsukuba.ac.jp/ tasae/2004/China\%20Mu.pdf

Yan-chun, G. (1998) Analysis on reasons for the Yellow River's dry-up and its eco-environmental impacts. Journal of Environmental Sciences 3 (10), 357-364.

YRCC (Yellow River Conservancy Commission) (ed.) (2001) Yellow River in the 20th Century. Yellow River Water Utilization Publisher, Zhengzhou, China. 